\title{
Characterisation and Assessment of Physicochemical Properties of Grapeseed Methyl Ester Using Predictive Correlations and ASTM Standards For CI Engine Application
}

\author{
C. Prabhu†, V. Rajasekar and T. Prakash \\ Department of Automobile Engineering, College of Engineering and Technology, SRM Institute of Science and \\ Technology, Kattankulathur-603203, Tamilnadu, India \\ $†$ Corresponding author: C. Prabhu; prabhuc@ srmist.edu.in
}

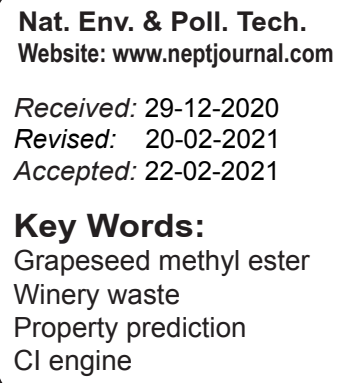

\begin{abstract}
In the present work, a detailed investigation of the physio-chemical characteristics of grapeseed methyl ester (GSME) obtained from winery biomass waste has been carried out to evaluate its suitability as an energy alternate, for $\mathrm{Cl}$ engines. GSME was subjected to Gas chromatography and mass spectrometry analysis from which fatty acids compositions were determined followed by other interpretations such as carbon number, number of double bonds, etc. Two different predictive correlations were identified from the literature for predicting the properties that are considered important, for using GSME as a fuel. The predicted properties of GSME are compared with the experimental results obtained through standard ASTM procedures, for diesel, neat grapeseed oil (GSO) and GSME, respectively. Further, the influence of the structural and compositional characteristics of GSME on the physicochemical properties like density, kinematic viscosity, lower calorific value, etc. has been evaluated and found to be closer to diesel.
\end{abstract}

\section{INTRODUCTION}

Diesel engines are the most sought-after systems deployed in the transportation sector, in power generation gensets for their utmost efficacy and low-cost factor. Conversely, as non-renewable fuel energy, diesel is also a major source of particulate matter (PM) causing adversities in health (Raheman \& Phadatare 2004). Albeit consistent efforts are being put up to mitigate these effects by investigating various possible energy resources, hardly there has been any significant development. However, with respect to compression ignition $(\mathrm{CI})$ engine application, the options are limited to mainly biodiesel (BD), as these come with the advantage of requiring fewer engine modifications. These BDs can be extracted from edible or non-edible sources. However, it is preferred to extract it from a non-edible resource (Singh et al. 2010) although it contains a high free fatty acid (FA) content, viscosity, and density, (Atabani et al. 2013, Gui et al. 2008). Thus far, many second-generation fuels such as sunflower, rapeseed, palm oil, etc. (Shahid \& Jamaal 2008), and third-generation fuels like waste cooking oil, waste tire oil, algae oil, bryophyte, etc. (Atabani et al. 2013, Sirohi et al. 2019) have been tested in CI engine application. Since the sources from which these oils are obtained are different, there exists a difference in FA contents and its percentage composition as well. Several research works have been carried to establish a correlation between the composition of the BD's and its properties.

Ramírez-Verduzco et al. (2012) had analyzed and presented in their work the characterization of the methyl ester of beef tallow and soybean oil. The impact of the molecular weight (MW) and unsaturation of the oils on the physiochemical properties were discussed in their work. Lapuerta et al. (2010) in their study had made attempts to compile the densities of ethyl esters and methyl esters available in the literature, at $15^{\circ} \mathrm{C}$, based on the chain length and unsaturation degree. Mehta and Anand (2009) had formulated an approach in determining the heating values of processed and straight vegetable oils based on the bond energies of their corresponding fatty esters. The closeness of predictions for the processed and straight vegetable oils with the existing experimental data was said to be within $3 \%$. Tong (2010) developed a model involving the fatty acid methyl ester (FAME) components for the determination of cetane number $(\mathrm{CN})$ of various BDs. MW and carbon number of the FA chain were correlated by developing two different regression equations. Islam et al. (2013) had examined the BD of different microalgal species by characterization through Preference Ranking Organisation Method for Enrichment Evaluation (PROMETHEE) to calculate the salient properties 
like iodine value, kinematic viscosity, etc. Efforts were made by Chuck et al. (2009) to generate a model for FAME composition using Matlab environment, fitting a quadratic response for saturation and average chain length.

Rao \& Rao (2008) had investigated the influence of (BD) properties on the engine characteristics. Two BD fuels namely, coconut oil and sesame seed oil methyl ester respectively, were selected. The authors had indicated that as the ratio of carbon to hydrogen $(\mathrm{C} / \mathrm{H})$ increases, the fuel had a tendency to produce more smoke emissions. The work carried out by Salamanca et al. (2012) showed the impact of the molecular structure of the moderately unsaturated palm oil and highly unsaturated linseed oil biodiesel and their blend ( $50 \%$ by volume) on PM emission. The sample oils were characterized using gas chromatography analysis and tested in an engine and compared with diesel soot emission.

\section{Motivation for the Present Study}

One of the progressive areas of business is the winery industry, which is a major source of voluminous liquid and solid waste, which mainly comprise grape pomace and seeds and serves as a source of oil (Fernández et al. 2010, Muhlack et al. 2018). Often, the handling, treatment, and discarding procedures of these solid wastes are complex and costlier (Ohnishi 1990, Bustamante et al. 2008). This opens up a broad avenue for extracting oil from winery waste, particularly, the grape seeds, and evaluate the suitability of GSO as fuel for CI engine applications. Moreover, not much work has been reported on the assessment of physiochemical characteristics and property prediction of the biofuel produced from grapeseed of winery industry waste which is the prime novelty of this work.

Hence, in the present work, the physiochemical characteristics of neat GSO and GSME were tested through ASTM standards and further subjected to Gas Chromatography-Mass Spectrometry analysis (GC-MS). The presence of different
FAs in the oils with its percentage composition can be found through this analysis (Hariram et al. 2020). Several other interpretations such as the presence of double bonds in each FA (indicating unsaturation level), carbon number, and the MW of the individual FA present in the oil were made. A comparative analysis was carried out between the physiochemical properties obtained through standard ASTM procedures and that of predicted values. These predicted values are obtained from the already established predictive correlations from literature, that is based on the inherent characteristics of the fuel such as carbon number, number of double bonds, etc., as these provide a close approximation of the physiochemical properties (Da Silva et al. 2017, Chai et al. 2014).

\section{MATERIALS AND METHODS}

\section{Transesterification}

In view of the fact that the viscosity of neat GSO chosen for this work was higher, the same has been converted into BD. Although several methods are available for reducing the viscosity of neat vegetable oil into BD. Trans-esterification is one of the methods which is most common and efficient (Martín 2010). As the free fatty acid (FFA) content of NGSO was lower $(0.25 \%)$, it was subjected to a single stage of esterification. The separated BD was then water washed twice and heated up to obtain the final yield of nearly $80 \%$.

\section{Characterisation of Grapeseed Methyl Ester}

To determine the nature of oil obtained and the extent to which a given sample of oil can be used as fuel, and FA profile analysis of GSME was carried out using Agilent GCMS. The specification of the GCMS setup is provided in Table 1.

\section{Physiochemical Properties Measurement}

One of the important aspects on which the performance of an

Table 1: Specifications of the GCMS setup.

\begin{tabular}{|ll|}
\hline GCMS for FA profile & ASTM D6584 \\
\hline Instrument Model & AGILENT GCMS : MSD 5977A AND GC7890B \\
Column & Agilent 19091S-433:93.92873 HP-5MS 5\% phenyl \\
& methyl silox $-60^{\circ} \mathrm{C}$ to $325^{\circ} \mathrm{C}\left(325^{\circ} \mathrm{C}\right)$ \\
& $30 \mathrm{mX} 250 \mu \mathrm{mX} 0.25 \mu \mathrm{m}$ \\
Software & MASS HUNTER \\
& Data compared with NIST library \\
& Scan range: $30-300 \mathrm{amu}$ \\
& Injection volume: $1 \mu \mathrm{L}$ through auto sampler \\
& Split ratio: $100: 1$ \\
& Helium gas $18.129 \mathrm{psi}:(1.489 \mathrm{~mL} / \mathrm{min}) \mathrm{MSD}$ Transfer line temp : $250^{\circ} \mathrm{C}$ Injector temp :250 ${ }^{\circ} \mathrm{C}$ \\
& $80^{\circ} \mathrm{C}$ for $2 \mathrm{~min}$ then ramped $130^{\circ} \mathrm{C}$ at $10^{\circ} \mathrm{C} / \mathrm{min}$ \\
then $210^{\circ} \mathrm{C}$ at $30^{\circ} \mathrm{C} / \mathrm{min}$ hold for $30 \mathrm{~min}$ with a total run time $44 \mathrm{mins}$ and Solvent delay of $2 \mathrm{~min}$
\end{tabular}


engine depends is the physicochemical properties of the fuel. As far as BDs are concerned, the physiochemical properties, which in turn are governed by the individual fatty esters present, could greatly influence the engine performance and combustion-related parameters, like, the mass of fuel injected fuel penetration. and atomization, etc. (Lapuerta et al. 2010). Hence, properties like the acid value, viscosity, density, cetane index, iodine value, and heating value of the FAME have been determined. The instruments and methods used for the measurements of properties are indicated in Table .2. For cetane index calculation, the procedure prescribed in ASTM D4737 was followed (Aleme \& Barbeira 2012).

Calculated Cetane Index $=45.2+(0.0892)$ $\left(\mathrm{T}_{10 \mathrm{~N}}\right)+[0.131+(0.901)(\mathrm{B})]\left[\mathrm{T}_{50 \mathrm{~N}}\right]+[0.0523-(0.420)(\mathrm{B})]$

$\left[\mathrm{T}_{90 \mathrm{~N}}\right]+[0.00049]\left[\left(\mathrm{T}_{10 \mathrm{~N}}\right)^{2}-\left(\mathrm{T}_{90 \mathrm{~N}}\right)^{2}\right]+107(\mathrm{~B})+(60)(\mathrm{B})^{2}$

Calculated Cetane Index by Four Variable Equation

$\mathrm{D}=$ Density at $15^{\circ} \mathrm{C}, \mathrm{g} / \mathrm{mL}, \mathrm{B}=\left[\exp ^{(-3.5)(\mathrm{D}-0.85)}\right]-1$

$\mathrm{T}_{10}=10 \%$ recovery temperature, ${ }^{\circ} \mathrm{C}, \mathrm{T}_{10 \mathrm{~N}}=\mathrm{T}_{10}-215$

$\mathrm{T}_{50}=50 \%$ recovery temperature, ${ }^{\circ} \mathrm{C}, \mathrm{T}_{50 \mathrm{~N}}=\mathrm{T}_{50}-260$

$\mathrm{T}_{90}=90 \%$ recovery temperature, ${ }^{\circ} \mathrm{C}, \mathrm{T}_{90 \mathrm{~N}}=\mathrm{T}_{90}-310$

\section{Predictive Correlations}

The overall properties of the $\mathrm{BD}$ will be based on each fatty ester that constitutes the BD. In turn, the characteristics of the individual fatty esters are governed by the structural features of the FA and its percentage composition. Researchers have formulated several correlations based on the fatty ester's inherent chemical characteristics such as the chemical structure, MW, double bonds, etc., Islam et al. (2013). The correlations that have been used in this work are shown in Table 3.

\section{RESULTS AND DISCUSSION}

\section{Gas Chromatography-Mass Spectrometry Results}

Fig. 1 shows the various peaks obtained at different intervals for GSME using GCMS and provides absolute quantification of the FAME's present in GSME. The values thus obtained from the spectral peaks of the GCMS is analyzed and the outcome indicates the presence of different fatty esters in GSME like methyl linoleate (C18:2-39.83\%), methyl stearate (C18:0 $25.13 \%)$, methyl palmitate (C16:0 - 17.37\%), methyl myristate $(\mathrm{C} 14: 0-3.048 \%)$ and methyl laurate $(\mathrm{C} 12: 0-2.378 \%)$ in major proportion by weight along with other compounds. Furthermore, double bonds in methyl linoleate and methyl eicosenoate and its percentage content, evidently indicate, that the oil is moderately unsaturated. The compounds which are present in very minor proportions have not been considered for analysis in this work. In addition, as the physicochemical

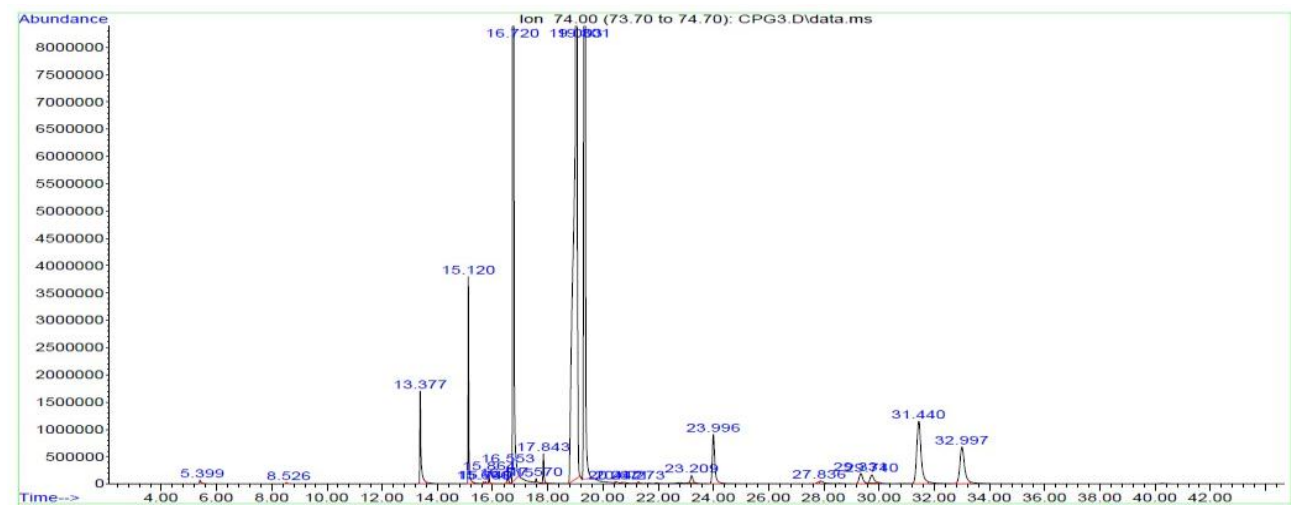

Fig. 1: Chromatogram generated by GCMS for GSME.

Table 2: Instruments and Standards for property measurement.

\begin{tabular}{|c|c|c|c|c|}
\hline S.No. & Properties & Instruments used & Measurement Standards & Accuracy \\
\hline 1. & $\begin{array}{l}\text { Specific gravity } \\
@ 15^{\circ} \mathrm{C}\end{array}$ & Weighted bulb hydrometer & ASTM D1298 & \pm 0.001 \\
\hline 2. & $\begin{array}{l}\text { Viscosity } \\
@ 40^{\circ} \mathrm{C}\end{array}$ & $\begin{array}{l}\text { Glass Viscometer } \\
\text { Brook Field Viscometer }\end{array}$ & ASTM D445 & $\pm 0.003 \mathrm{cSt}$ or $\mathrm{mm}^{2} / \mathrm{s}$ \\
\hline 3. & Heating value, $\mathrm{MJ} / \mathrm{kg}$ & CC01/M3 Bomb calorimeter & ASTM D240 & $\pm 0.001^{\circ} \mathrm{C}$ \\
\hline 4. & Iodine value & Wij's method & IS 548 Part 1,1964 & - \\
\hline 5. & Cetane Index & $\begin{array}{l}\text { Distillation temperature (90\% recovered) - Thermo- } \\
\text { couple, Flask, with distillation arrangement }\end{array}$ & ASTM D4737 & $\pm 0.1^{\circ} \mathrm{C}$ \\
\hline
\end{tabular}


Table 3: Predictive correlations based on carbon, hydrogen, oxygen, MW, and number of double bonds.

\begin{tabular}{|c|c|c|}
\hline Properties & $\begin{array}{l}\text { Correlations based on MW, Carbon number, Hydrogen, and Oxygen content, and Number of double bonds } \\
\text { of the FAME (FAME) }\end{array}$ & References \\
\hline \multirow[t]{2}{*}{ Density } & $\begin{array}{l}\mathrm{D}=0.8463+4.9 / \mathrm{M}_{\mathrm{i}}+0.018 \mathrm{~N}_{\text {th }} \\
\text { where } \mathrm{M}_{\mathrm{i}} \text { is the } \mathrm{MW} \text { of the } \mathrm{i} \text { FAME and } \mathrm{N} \text { is the } \\
\text { number of double bonds in the FAME }\end{array}$ & $\begin{array}{l}\text { Ramirez et al. } \\
(2012)\end{array}$ \\
\hline & $\begin{array}{l}\mathrm{D}=851.471+[250.718 \mathrm{db}+280.899] / 1.214+\mathrm{n} \\
\text { Where } \mathrm{db} \text { is the number of double bonds in the FAME, } \mathrm{n} \text { is the carbon number of the FAME. }\end{array}$ & Lapuerta et al. (2010) \\
\hline \multirow[t]{2}{*}{ Viscosity } & $\begin{array}{l}\ln \left(V_{i}\right)=-12.503+2.496 \ln \left(M_{i}\right)-0.178 N \\
\text { where } M_{i} \text { is the molecular weight of the } i{ }^{\text {th }} \text { FAME and } N \text { is the } \\
\text { number of double bonds in the FAME }\end{array}$ & Ramirez et al. (2012) \\
\hline & $\begin{array}{l}\eta=0.235 \mathrm{Nc}-0.699 \mathrm{~N}_{\mathrm{DB}}, \\
\text { where } \eta \text { is the kinematic viscosity of the FAME, Where } \mathrm{Nc}=\text { No. of carbon atoms, } \mathrm{NDB}^{\mathrm{III})} \text { No. of double } \\
\text { bonds }\end{array}$ & Chang \& Liu (2009) \\
\hline \multirow[t]{2}{*}{$\begin{array}{l}\text { Lower heating } \\
\text { value }\end{array}$} & $\begin{array}{l}\mathrm{LHV}=0.0109(\mathrm{C} / \mathrm{O}) \exp 3-0.3516(\mathrm{C} / \mathrm{O}) \exp (2)+4.2000(\mathrm{C} / \mathrm{O})+21.066-0.11 \mathrm{~N}_{\mathrm{db}} \\
\text { where } \mathrm{C} \text { and } \mathrm{O} \text { are the percentage weights of Carbon and Oxygen respectively and } \mathrm{N}_{\mathrm{db}} \text { is the number of } \\
\text { double bonds in the FAME }\end{array}$ & $\begin{array}{l}\text { Mehta \& } \\
\text { Anand (2009) }\end{array}$ \\
\hline & $\begin{array}{l}\mathrm{LHV}=0.0011(\mathrm{H} / \mathrm{O}) \exp 3-0.0785(\mathrm{H} / \mathrm{O}) \exp (2)+2.0409(\mathrm{H} / \mathrm{O})+20.992-0.100 \mathrm{~N}_{\mathrm{db}} \\
\text { where } \mathrm{C}, \mathrm{H} \text {, and } \mathrm{O} \text { are the percentage weight of carbon, hydrogen, and oxygen, respectively }\end{array}$ & $\begin{array}{l}\text { Mehta \& } \\
\text { Anand (2009) }\end{array}$ \\
\hline \multirow[t]{2}{*}{$\begin{array}{l}\text { Cetane } \\
\text { Number }\end{array}$} & $\begin{array}{l}\mathrm{CN}=-52.974+\left(13.767-1.202 \mathrm{db}+0.152 \mathrm{db}^{2}\right) \mathrm{X}-0.351 \mathrm{X}^{2} \\
\text { Where } \mathrm{db} \text { is the number of double bonds in the FAME, and ' } \mathrm{X} \text { ' is the Carbon number of the FA }\end{array}$ & Tong et al. (2011) \\
\hline & $\begin{array}{l}\mathrm{CN}=-23.523+\left(2.366+6.299 \mathrm{e}^{-0.411 \mathrm{db}}\right) \mathrm{n} \mathrm{X} \exp ^{-(0.018 \mathrm{n})} \\
\text { Where } \mathrm{db} \text { is the number of double bonds in the FAME, and } \mathrm{n} \text { is the Carbon number of the FA }\end{array}$ & Lapuerta et al. (2010) \\
\hline \multirow[t]{2}{*}{ Value } & $\begin{array}{l}\text { IV }=\left(\% \mathrm{C}_{16: 1} \mathrm{X} 0.95\right)+\left(\% \mathrm{C}_{18: 1} \mathrm{X} 0.86\right)+\left(\% \mathrm{C}_{18: 2} \times 1.723+\left(\% \mathrm{C}_{18: 3} \mathrm{X} 2.616\right)+\left(\% \mathrm{C}_{20: 1} \mathrm{X} 0.785\right)\right. \\
+\left(\% \mathrm{C}_{22: 1} \mathrm{X} 0.723\right) \\
\mathrm{C} \mathrm{x}: \mathrm{y}-\text { where } \mathrm{x} \text { is the carbon number and } \mathrm{y} \text { is the number of double bonds }\end{array}$ & Da Silva et al. (2017) \\
\hline & $\begin{array}{l}\text { IV }=\Sigma(254 \times \mathrm{D} X \mathrm{~A}) / \mathrm{MW} \\
\text { where } \mathrm{D} \text { is the density, } \mathrm{A}_{\mathrm{f}} \text { is the percentage content and } \mathrm{MW}_{\mathrm{i}} \text { is the } \\
\text { MW of the FAME's }\end{array}$ & Islam et al. (2013) \\
\hline
\end{tabular}

properties of the FAME has larger dependability on the inherent chemical characteristics such as carbon number, the number of double bonds, MW, etc., a close prediction of the physicochemical properties of the methyl ester can be arrived at (Tong 2010, Knothe 2005, Maroto et al. 2010).

Several interpretations that have been made from the different compounds identified from the sample of GSME have also been listed in Table.4. Further, it is seen that with the increasing carbon number, the MW of the fatty esters increases while the percentage content of oxygen decreases. The data thus interpreted, was substituted in two different correlations that have been chosen from different literature for each property such as density, viscosity, heating value, etc. which are considered to be important from the point of view of the performance of GSME in a CI engine. The predicted property values thus derived from the correlations are indicated in the parenthesis and further been quantified based on the percentage composition of the individual fatty esters, as indicated in Table.5.

\section{Physical Properties Variation}

Although the dependence of properties on structural characteristics of the ester may not be clearly evident from the values based on the FA percentage composition, the actual predicted values (in parenthesis) in Table 5 do exhibit a correlation as explained below. For instance, methyl caprylate which has an oxygen weight percentage of 22.19 has a

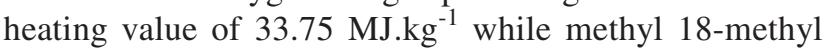
nonadecanoate with an oxygen percentage of 9.79 has a

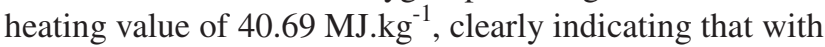
the increasing oxygen percentage, the fatty esters tend to have a proportionally lower energy density, while carbon number has a positive correlation with heating value. In a similar context, a correlation can be arrived, between the MWs of the individual ester composition with density, cetane index, and kinematic viscosity respectively, while a close correlation can also be arrived at, between lower heating value (LHV) of the esters and $\mathrm{C}: \mathrm{H}$ and $\mathrm{C}: \mathrm{O}$, respectively.

Fig. 2 shows the variation of density with MW of individual fatty ester composition. Although there is a decreasing trend for density with an increase in MW from $158.13 \mathrm{~g} \cdot \mathrm{mol}^{-1}$ for methyl caprylate to $284.27 \mathrm{~g} \cdot \mathrm{mol}^{-1}$ for methyl margarate, a sharp deviation from this trend is noticed for methyl linoleate and methyl eicosenoate. On the other hand, viscosity and cetane index has a positive correlation with MW. It is 


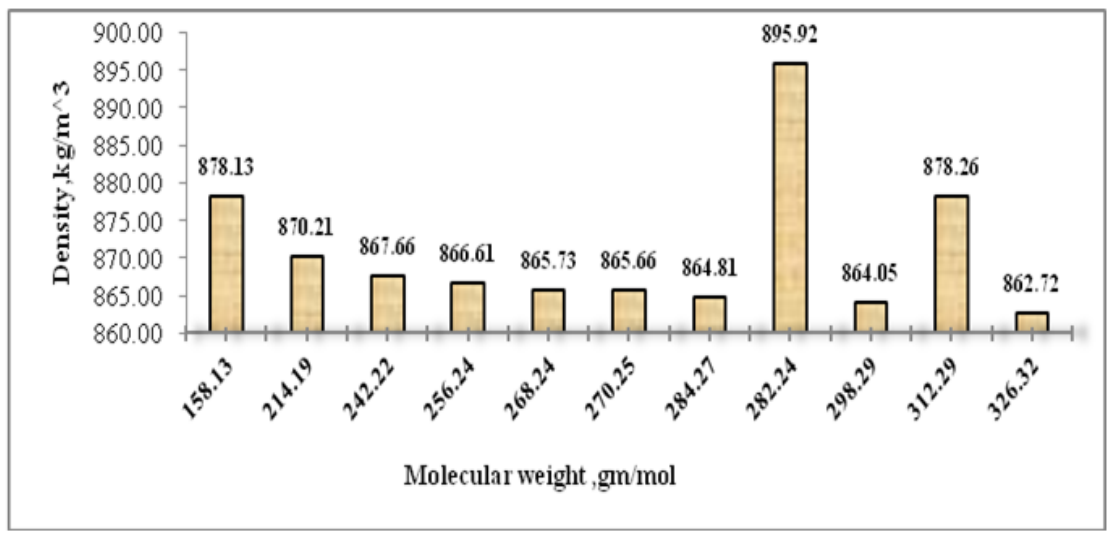

Fig. 2: Variation of density ${ }_{(\text {avg) }}$ with a molecular weight.

Table 4: Percentage content of the fatty esters, number of double bonds, and weight percentage of $\mathrm{C}, \mathrm{H}$, and $\mathrm{O}$.

\begin{tabular}{|c|c|c|c|c|c|c|c|c|c|c|c|}
\hline $\begin{array}{l}\text { S. } \\
\text { No. }\end{array}$ & Compound Name & $\begin{array}{l}\text { Per- } \\
\text { centage } \\
\text { content }\end{array}$ & $\begin{array}{l}\text { Molecular } \\
\text { formula }\end{array}$ & $\begin{array}{l}\text { Carbon } \\
\text { Num- } \\
\text { ber }\end{array}$ & $\begin{array}{l}\text { No. of } \\
\text { double } \\
\text { bond }\end{array}$ & $\begin{array}{l}\text { Molecular } \\
\text { Weight } \\
(\mathrm{g} / \mathrm{mol})\end{array}$ & $\mathrm{C}(\%)$ & $\begin{array}{l}\mathrm{H} \\
(\%)\end{array}$ & $\mathrm{O}(\%)$ & $\mathrm{C}: \mathrm{H}$ & $\mathrm{C}: \mathrm{O}$ \\
\hline 1 & Methyl Caprylate & 0.141 & $\mathrm{C}_{9} \mathrm{H}_{18} \mathrm{O}_{2}$ & 9 & 0 & 158.13 & 68.4 & 11.2 & 20.1 & 6.12 & 3.40 \\
\hline 2 & Methyl Laurate & 2.378 & $\mathrm{C}_{13} \mathrm{H}_{26} \mathrm{O}_{2}$ & 13 & 0 & 214.19 & 72.9 & 12.2 & 14.8 & 5.96 & 4.91 \\
\hline 3 & Methyl Myristate & 3.048 & $\mathrm{C}_{15} \mathrm{H}_{30} \mathrm{O}_{2}$ & 15 & 0 & 242.22 & 74.4 & 12.5 & 13.1 & 5.96 & 5.67 \\
\hline 4 & $\begin{array}{l}\text { Methyl Pentade- } \\
\text { canoate }\end{array}$ & 0.17 & $\mathrm{C}_{16} \mathrm{H}_{32} \mathrm{O}_{2}$ & 16 & 0 & 256.24 & 74.9 & 12.6 & 12.4 & 5.96 & 6.04 \\
\hline 5 & $\begin{array}{l}\text { Methyl Palmi- } \\
\text { toleate }\end{array}$ & 0.285 & $\mathrm{C}_{17} \mathrm{H}_{32} \mathrm{O}_{2}$ & 17 & 0 & 268.24 & 76.1 & 12.0 & 11.9 & 6.34 & 6.42 \\
\hline 6 & Methyl Palmitate & 17.37 & $\mathrm{C}_{17} \mathrm{H}_{34} \mathrm{O}_{2}$ & 17 & 0 & 270.25 & 75.5 & 12.7 & 11.8 & 5.97 & 6.42 \\
\hline 7 & $\begin{array}{l}\text { Methyl Marga- } \\
\text { rate }\end{array}$ & 0.647 & $\mathrm{C}_{18} \mathrm{H}_{36} \mathrm{O}_{2}$ & 18 & 0 & 284.27 & 76.0 & 12.8 & 11.2 & 5.96 & 6.80 \\
\hline 8 & Methyl Linoleate & 39.829 & $\mathrm{C}_{18} \mathrm{H}_{34} \mathrm{O}_{2}$ & 18 & 2 & 282.24 & 76.6 & 12.1 & 11.3 & 6.31 & 6.80 \\
\hline 9 & Methyl Stearate & 25.13 & $\mathrm{C}_{19} \mathrm{H}_{38} \mathrm{O}_{2}$ & 19 & 0 & 298.29 & 76.5 & 12.8 & 10.7 & 5.97 & 7.18 \\
\hline 10 & $\begin{array}{l}\text { Methyl Eicose- } \\
\text { noate }\end{array}$ & 0.343 & $\mathrm{C}_{20} \mathrm{H}_{40} \mathrm{O}_{2}$ & 20 & 1 & 312.29 & 76.9 & 12.9 & 10.2 & 5.97 & 7.56 \\
\hline 11 & $\begin{array}{l}\text { Methyl } 18-\text { me- } \\
\text { thyl Nonade- } \\
\text { canoate }\end{array}$ & 2.657 & $\mathrm{C}_{21} \mathrm{H}_{42} \mathrm{O}_{2}$ & 21 & 0 & 326.32 & 77.3 & 13.0 & 9.7 & 5.96 & 7.93 \\
\hline 12 & $\begin{array}{l}\text { Weight of } \mathrm{C}, \mathrm{H} \\
\text { and } \mathrm{O} \text { in the mix- } \\
\text { ture }(\mathrm{g} / \mathrm{mol}) \text {. }\end{array}$ & - & - & - & - & 2816.62 & 2113.7 & 350.4 & 351.78 & - & - \\
\hline 13 & $\begin{array}{l}\text { Composition in } \\
\text { the mixture by } \\
\text { weight percent }\end{array}$ & - & - & - & - & - & 75.06 & 12.44 & 12.48 & - & - \\
\hline
\end{tabular}

understood that the viscosity increases from $1.63 \mathrm{cSt}$ to 5.96 $\mathrm{cSt}$, and the cetane index increases from 42.65 to 91.26 , for the ester composition having MW's from $158.13 \mathrm{~g} . \mathrm{mol}^{-1}$ to 326.32 g.mol ${ }^{-1}$ respectively, for GSME. However, a similar deviation in the trend is observed for methyl linoleate and methyl eicosenoate as shown in Fig.3.
The reason that can be cited for such a deviation in trend for density, viscosity, and cetane index for both the fatty esters mentioned above could be due to the presence of double bonds in it, at a fairly considerable proportion making the oil moderately unsaturated. It can be seen that the iodine values computed through both the predictive correlation have values 


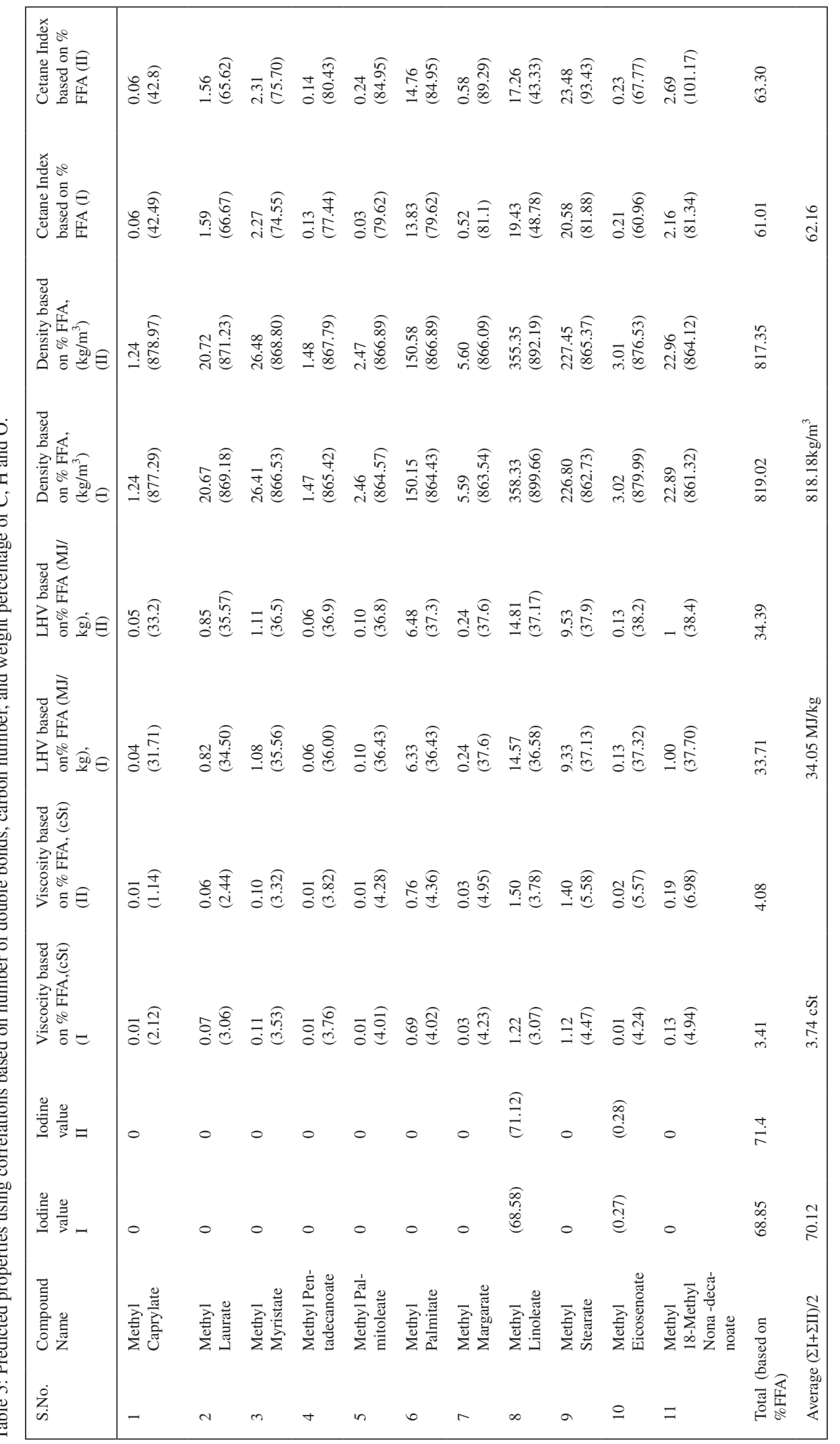

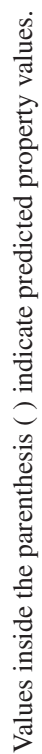


of 68.85 and 71.4 respectively, thereby reinforcing the above statement. Giakoumis (2013) had reported in their work for different BDs, a drop in viscosity level and cetane index for unsaturated esters, while it increased for saturated esters. Similar correlations used by Chang and Liu (2010) based on the number of carbon atoms and double bonds resulted in an average relative deviation of $6.78 \%$ for 30 experimental data points for MW and $13.97 \%$ deviation for kinematic viscosity prediction for 60 experimental data points. Compared to the average percentage deviation between the experimental and predicted value of the various BDs used by them, the observed deviation in this work for MW and kinematic viscosity is comparatively lesser as can be inferred from Table 6.

Generally, the lower heating value for BD ranges from an average of $33{\mathrm{MJ} . \mathrm{kg}^{-1}}^{-1}$ to $38 \mathrm{MJ} \cdot \mathrm{kg}^{-1}$ which is nearly 10 to $12 \%$ lower than diesel fuel. For GSME, the variation of LHV with carbon to oxygen ratio and carbon to hydrogen ratio for its fatty ester composition is shown in Fig.4 and 5 respectively. The lower heating value was found to be $31.28{\mathrm{MJ} . \mathrm{kg}^{-1} \text { for }}^{-1}$

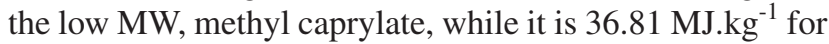
the higher MW, methyl 18-methyl nonadecanoate. However, a very close correlation can be observed between LHV and $\mathrm{C}: \mathrm{O}$ and $\mathrm{C}: \mathrm{H}$, respectively. It is therefore evident, that as the oxygen content in the fatty esters decreases or the carbon content increases, the lower heating value of the esters increases. Further, FAMEs with similar $\mathrm{C}: \mathrm{O}$ but lower $\mathrm{C}: \mathrm{H}$ ratios (i.e. more hydrogen) exhibit greater $\mathrm{LHV}$ which was the case for methyl palmitoleate and methyl palmitate. However, with progressively greater levels of unsaturation, the energy content reduces. Similar results have been reported by Ramírez-Verduzco et al. (2012).

\section{Comparison of Experimental and Predicted Property Results}

Since the present investigation deals with the characterization and evaluation of properties of GSO for use in CI engine application, a comparison of the properties of neat GSO and GSME (predicted and test results) is made with diesel. It can be inferred from Table. 6, that NGSO has a specific gravity, kinematic viscosity, cetane index, and heating value of 0.91 ,

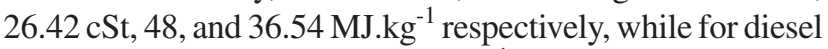

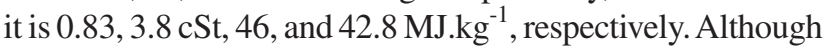
the cetane value of neat GSO is closer to diesel, the kinematic viscosity and density are much higher than diesel which could lead to increased fuel consumption, poor atomization, and combustion.

Further, the density, kinematic viscosity, lower heating value, and cetane index of GSME determined through ASTM standards and the average of I and II predicted from correlations are shown in Table. 6 with their percentage variation, respectively. Since the percentage variation between the experimental results and the predicted results are not high, it can be concluded that the determination of the properties using predictive correlations are in close agreement with the experimental values and also falls within the acceptable range specified in the international standards as can be seen in Table .6.

Moreover, as the properties of GSME is closer to diesel, lower fuel consumption and better atomization compared to NGSO can be expected, eventually leading to better performance, combustion, and emission characteristics when used as a fuel for CI engine application.

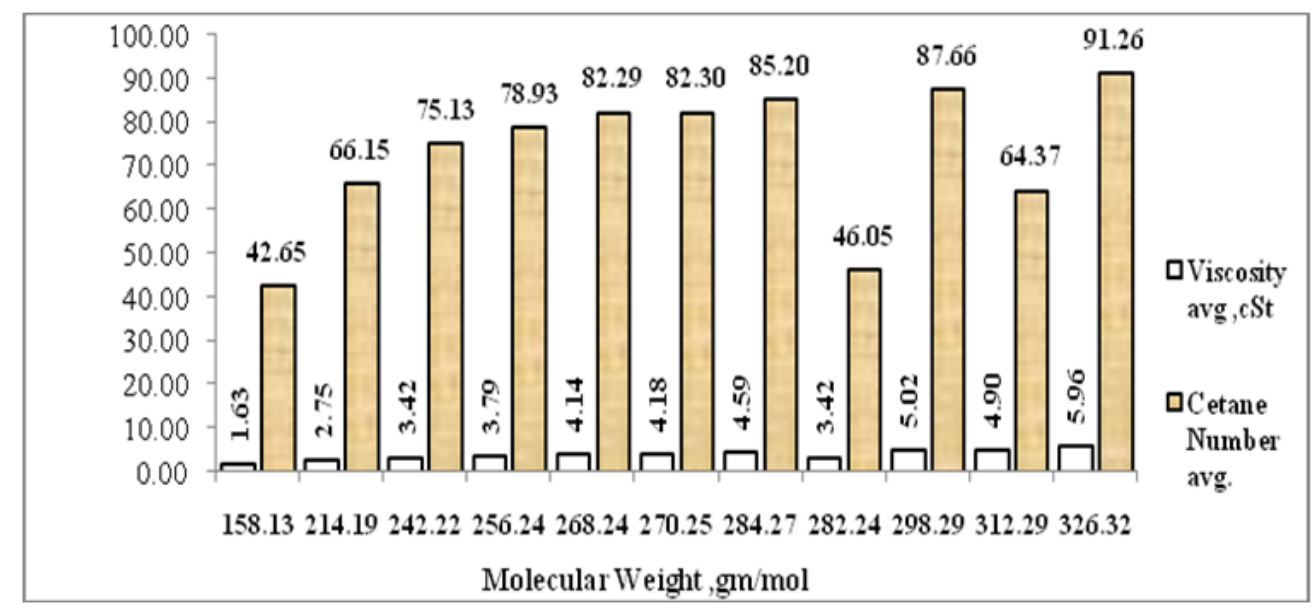

Fig. 3: Variation of kinematic viscosity (avg) and cetane index (avg) with MW. 


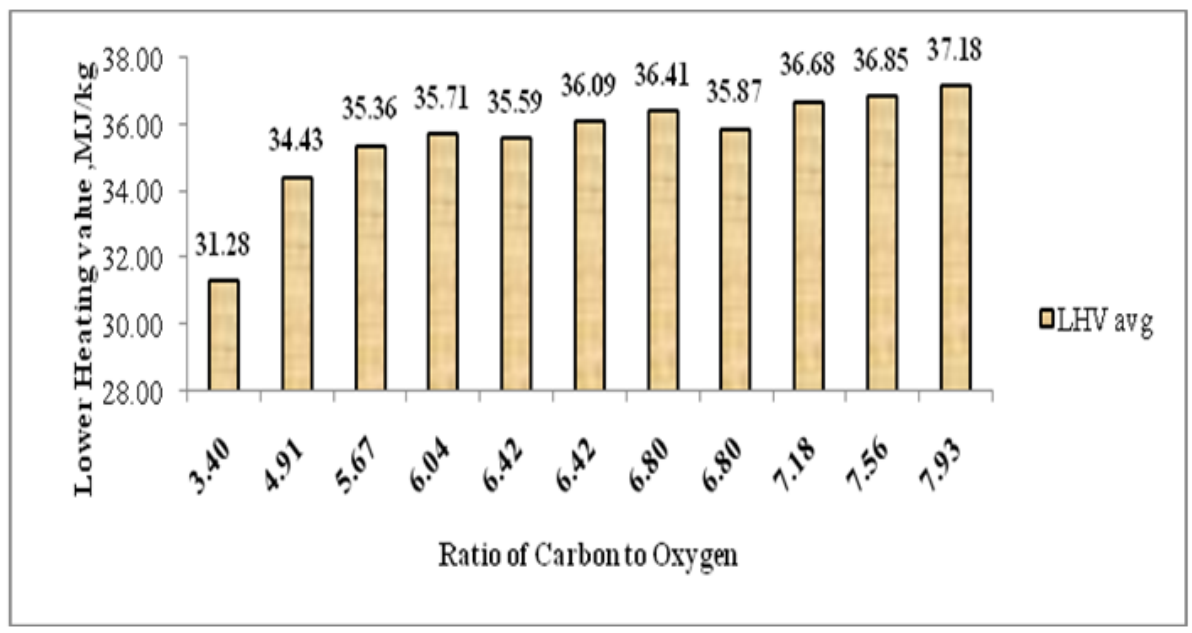

Fig. 4: Variation of lower heating value ${ }_{(a v g)}$ with carbon to oxygen ratio for GSME.

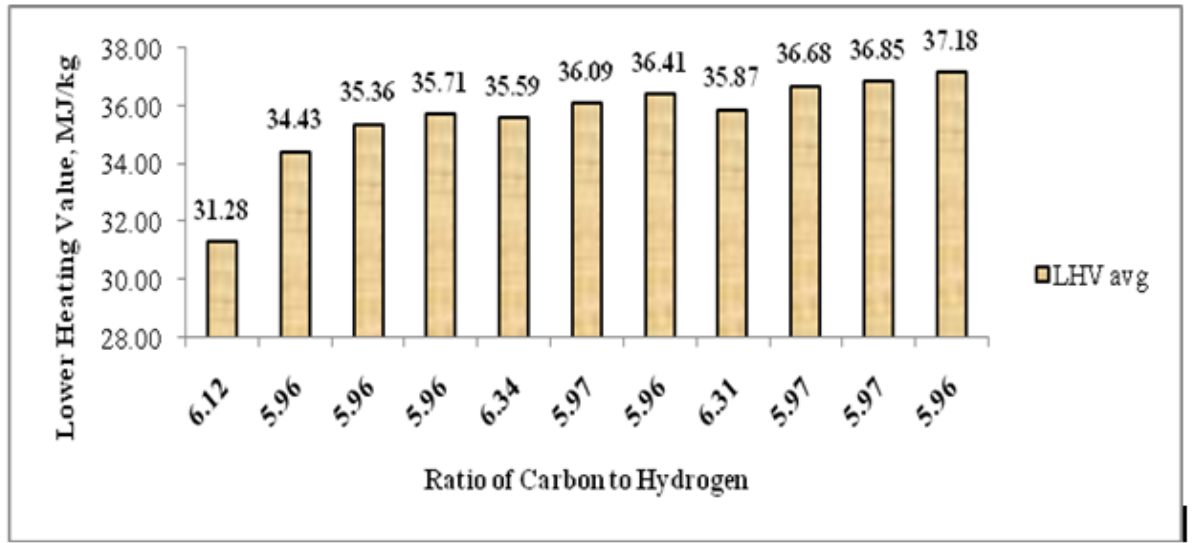

Fig. 5: Variation of lower heating value ${ }_{(\text {avg) }}$ with carbon to hydrogen ratio for GSME.

\section{CONCLUSIONS}

1. The inputs to predictive correlations such as MW, number of double bonds, carbon number, etc. were interpreted from GCMS analysis for individual fatty ester composition.

2. A close correlation is observed between individual fatty ester MW and density, kinematic viscosity, and cetane index, respectively. For saturated esters of GSME, with an increase in MW, density decreases from 878.13 $\mathrm{kg} \cdot \mathrm{m}^{-3}$ to $862.72 \mathrm{~kg} \cdot \mathrm{m}^{-3}$ for methyl caprylate to methyl margarate having MW of $158.13 \mathrm{~g} \cdot \mathrm{mol}^{-1}$ and 284.27 g. $\mathrm{mol}^{-1}$ respectively. However, this effect is contradicting for methyl linoleate and methyl eicosenoate which are unsaturated.
3. Similarly, viscosity and cetane index have a positive correlation with MW. It is understood that the viscosity increases from $1.63 \mathrm{cSt}$ to $5.96 \mathrm{cSt}$ and the cetane index increases from 42.65 to 91.26 for the ester composition having MWs from 158.13 g.mol ${ }^{-1}$ to $326.32 \mathrm{~g} \cdot \mathrm{mol}^{-1}$ respectively for GSME.

4. In addition, $\mathrm{C}: \mathrm{O}$ and $\mathrm{C}: \mathrm{H}$ are found to have a close correlation with the lower heating value of the fuel with lower carbon to oxygen ratio exhibiting lower LHV, and lower carbon to hydrogen ratio exhibiting higher LHV.

5. Experimental evaluation of properties of GSME through ASTM standards is in close agreement with predicted values.

On the whole, as the properties of GSME are closer to 
Table 6: Property comparison of NGSO and GSME with diesel.

\begin{tabular}{|c|c|c|c|c|c|}
\hline \multirow[t]{2}{*}{ Properties } & \multicolumn{3}{|c|}{ Experimental } & \multirow{2}{*}{$\begin{array}{l}\text { Average values predicted } \\
\text { (based on \% FFA) for GSME }\end{array}$} & \multirow{2}{*}{$\begin{array}{l}\text { (Experimental } \\
\& \text { Predicted) \% variation }\end{array}$} \\
\hline & Diesel & NGSO & GSME & & \\
\hline $\begin{array}{l}\text { Density @ } \\
15^{\circ} \mathrm{C}\end{array}$ & 830 & 910 & 841 & 818.18 & 2.75 \\
\hline $\begin{array}{l}\text { Kinematic viscosity } \\
(\mathrm{cSt}),\left(40^{\circ} \mathrm{C}\right)\end{array}$ & 3.80 & 26.42 & 4.04 & 3.74 & 7.71 \\
\hline $\begin{array}{l}\text { Low Heating } \\
\text { Value }(\mathrm{MJ} / \mathrm{kg})\end{array}$ & 42.8 & 36.54 & 36.82 & 34.05 & 7.82 \\
\hline Cetane Index & 47 & 46.3 & 59.99 & 62.16 & 3.55 \\
\hline Iodine Number & - & 72 & 66 & 70.12 & 6.05 \\
\hline
\end{tabular}

diesel, lower fuel consumption and better atomization compared to NGSO can be achieved, eventually leading to better performance, combustion, and emission characteristics when used as fuel for CI engine application.

\section{REFERENCES}

Aleme, H.G. and Barbeira, P.J., 2012. Determination of flash point and cetane index in diesel using distillation curves and multivariate calibration. Fuel, 102: 129-134.

Atabani, A.E., Silitonga, A.S., Ong, H.C., Mahlia, T.M.I., Masjuki, H.H., Badruddin, I.A. and Fayaz, H. 2013. Non-edible vegetable oils: A critical evaluation of oil extraction, FA compositions, BD production, characteristics, engine performance, and emissions production. Renew. Sust. Energy Rev., 18: 211-245.

Bustamante, M.A., Moral, R., Paredes, C., Pérez-Espinosa, A., Moreno-Caselles, J. and Pérez-Murcia, M.D., 2008. Agrochemical characterization of the solid by-products and residues from the winery and distillery industry. Waste Manag., 28(2): 372-380.

Chai, M., Tu, Q., Lu, M. and Yang, Y.J. 2014. Esterification pretreatment of free fatty acid in BD production, from laboratory to industry. Fuel Process. Technol., 125: 106-113.

Chang, A.F. and Liu, Y.A. 2010. Integrated process modeling and product design of BD manufacturing. Ind. Eng. Chem. Res., 49(3): 1197-1213.

Chuck, C.J., Bannister, C.D., Hawley, J.G., Davidson, M. G., La Bruna, I. and Paine, A. (2009). A predictive model to assess the molecular structure of BD fuel. Energ. Fuels, 23(4): 2290-2294.

Da Silva, F.L., do Nascimento, J.R., de Melo, L.N., de Freitas, J.A.S., Bortoluzzi, J.H. and Meneghetti, S.M.P., 2017. Study of correlations between composition and physicochemical properties during methylic and ethylic BD synthesis. Ind. Crops Prod., 95: 18-26.

Fernández, C.M., Ramos, M.J., Pérez, Á. and Rodríguez, J.F. 2010. Production of BD from winery waste: Extraction, refining and transesterification of GSO. Bioresour. Technol., 101(18): 7019-7024.

Giakoumis, E.G. 2013. A statistical investigation of BD physical and chemical properties, and their correlation with the degree of unsaturation. Renewable Energy, 50: 858-878.

Gui, M.M., Lee, K.T. and Bhatia, S. 2008. Feasibility of edible oil vs. non-edible oil vs. waste edible oil as BD feedstock. Energy, 33(11): 1646-1653.

Hariram, V., Karthikeyan, N.B., Seralathan, S., Premkumar, T.M. and John, J.G. 2020. Spectroscopic characterization of palm stearin BD derived through base catalyzed transesterification process. Nature Environ. Pollut. Technol., 19(3): 981-990.

Islam, M.A., Magnusson, M., Brown, R.J., Ayoko, G.A., Nabi, M.N. and Heimann, K. 2013. Microalgal species selection for BD production based on fuel properties derived from fatty acid profiles. Energies, 6(11): 5676-5702.

Knothe, G. 2005. Dependence of BD fuel properties on the structure of fatty acid alkyl esters. Fuel Process. Technol., 86 (10): 1059-1070.

Lapuerta, M., Rodríguez-Fernández, J. and Armas, O. 2010. Correlation for the estimation of the density of fatty acid esters fuels and its implications. A proposed BD cetane index. Chem. Phy. Lipids, 163(7): 720-727.

Maroto, J.A., Quesada-Pérez, M. and Ortiz-Hernández, A.J. 2010. Use of kinematic viscosity data for the evaluation of the molecular weight of petroleum oils. J. Chem. Educ., 87(3): 323-325.

Martín, C. 2010. Fractional characterization of jatropha, neem, moringa, trisperma, castor, and candlenut seeds as potential feedstocks for BD production in Cuba. Biomass Bioenerg., 34(4): 533-538.

Mehta, P.S. and Anand, K. 2009. Estimation of a lower heating value of vegetable oil and BD Fuel. Energ. Fuels, 23(8): 3893-3898.

Muhlack, R.A., Potumarthi, R. and Jeffery, D.W. 2018. Sustainable wineries through waste valorization: A review of grape marc utilization for value-added products. Waste Management, 72, 99-118.

Ohnishi, M. 1990. Chemical composition of lipids, especially triacylglycerol, in grape seeds. Agric. Biol. Chem., 54(4):1035-1042.

Raheman, H. and Phadatare, A.G. 2004. Diesel engine emissions and performance from blends of karanja methyl ester and diesel. Biomass and Bioenerg., 27(4): 393-397.

Ramírez-Verduzco, L.F., Rodríguez-Rodríguez, J.E. and Jaramillo-Jacob, A. R. 2012. Predicting cetane number, kinematic viscosity, density and higher heating value of BD from its FAME composition. Fuel, 91(1): 102-111.

Rao, V.P. and Rao, B.V.A. 2008. Influence of Physical and Chemical Properties of Two BD Fuels on Performance, Combustion and Exhaust Emission Characteristics in a DI-CI Engine. ASME 2008 Internal Combustion Engine Division Spring Technical Conference.

Salamanca, M., Mondragón, F., Agudelo, J.R., Benjumea, P. and Santamaría, A. 2012. Variations in the chemical composition and morphology of soot induced by the unsaturation degree of $\mathrm{BD}$ and a BD blend. Combust. Flame, 159(3): 1100-1108.

Shahid, E.M. and Jamal, Y. 2008. A review of BD as a vehicular fuel. Renew. Sust. Energy Rev., 12(9): 2484-2494.

Singh, P.J., Khurma, J. and Singh, A. 2010. Preparation, characterization, engine performance, and emission characteristics of coconut oil-based hybrid fuels. Renew. Energy, 35(9): 2065-2070.

Sirohi, S., Yadav, C. and Banerjee, D. 2019. Biofuel from Bryophyta as an alternative fuel for the future. Nature Environ. Pollut. Technol., 18(3): 889-895.

Tong, D. 2010. Cetane number prediction of BD from the composition of the fatty acid methyl esters. J. Amer. Oil Chem. Society, 88(3): 415-423. 